\title{
Beagle cash dogged by dissent over wording
}

Mark Peplow, London

Britain's failed Mars lander, Beagle 2, has ignited a row over money - $€ 16$ million (US\$20 million) that the European Space Agency (ESA) provided four years ago to keep the project going.

Disagreement about the conditions under which the money was handed over and whether Britain is to repay it - has surfaced at senior levels in the space agency. David Southwood, ESA's scientific director, says it is unlikely that the agency will again allocate so much cash to a project on such an informal basis.

The transfer was agreed by ESA's Science Programme Committee, which allocates funds for agency projects, at two meetings in October and November 2000. The committee decided that ESA should allot $€ 24$ million to the Beagle probe, a late addition to the agency's Mars mission. The probe subsequently went missing while attempting to land on Mars on 19 December 2003.

One-third of the money went to preparing ESA's Mars Express spacecraft to carry the probe. But two-thirds of it was described at the meetings as a "loan", senior scientists tell Nature.

"The word 'loan' was used," said Risto Pellinen in an interview. Pellinen, an atmospheric physicist at the Finnish Meteorological Institute in Helsinki, was on the committee at the time and now chairs it. But he says the money was not in fact a loan, and was not meant to be paid back as cash. The word was used, he says, "because we are not native English speakers - we can't fine-tune our language".

The minutes of the October meeting state

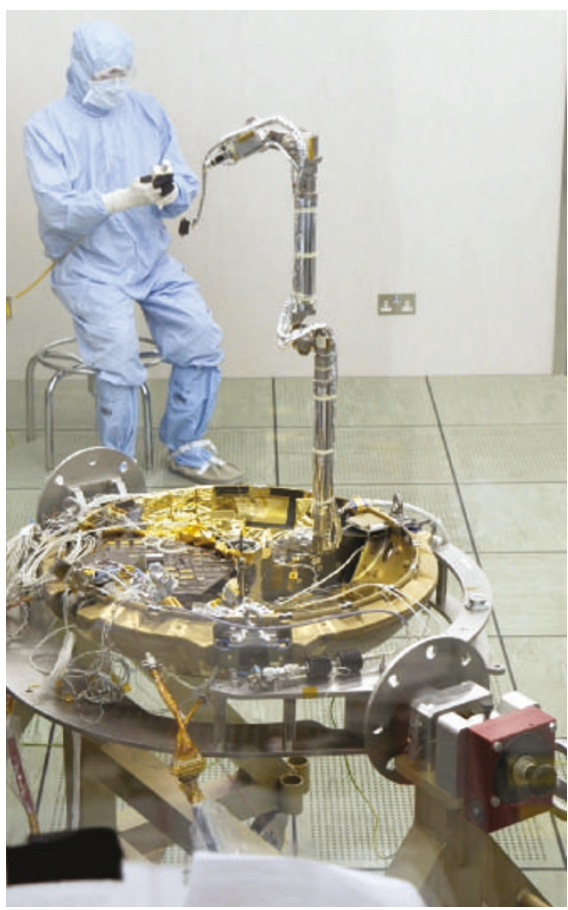

Funding for Beagle 2, which was later lost on Mars, is still regarded by some as a 'loan'.

that "the science programme would be reimbursed the sum of $€ 16$ million" by Britain. The committee members, and Southwood, say that the wording was meant to imply that Britain would repay the contribution by providing goods and services to that value for future ESA missions.

The meetings discussed the possibility of a UK contribution towards Gaia, a proposed star-mapping mission due for launch some time after 2010. But four years after the agreement, there is no indication of what Britain is planning to do. "What leaves a funny taste is this attitude that no one speaks about it any more," complains one senior space scientist who is knowledgeable about the arrangement but declined to be identified. He suggests that everyone would be happier if Britain repaid the money in cash: "A cheque for $€ 16$ million would be best."

Southwood says that David Sainsbury, the UK science minister, wrote to the committee at the time promising to do his best to recompense ESA. But Southwood insists that no one expected it to be paid back in cash: "It was a gentleman's agreement. You can't really call it a loan, it was a quid pro quo."

He concedes that it is unlikely that ESA will ever again grant so much money on such a basis. "I'm not convinced people are gentlemen any more," he adds ruefully.

Britain has no firm plan for how it will reimburse the space agency, says David Leadbeater, deputy director-general of the British National Space Centre. "There's nothing that says this must be sorted out in the context of a particular mission," he says, adding that he expects that the money will be repaid through contributions in kind to future projects. "There is still a commitment to resolve this to the satisfaction of all ESA members," insists Leadbeater.

Pellinen defends the arrangement. "In my opinion, this was the only way to get things done in the available time," he says. But he thinks negotiations about recompense are pointless until Gaia is ready for development in late 2005 - after the end of his chairmanship. "This matter will not be forgotten," he promises.

\section{NIH researchers face blanket consulting ban}

\section{Emma Marris, Washington}

The National Institutes of Health (NIH) has announced plans to ban its scientists from carrying out any paid consultancy work for biotechnology and pharmaceutical companies for 12 months.

In a memo to staff on 24 September, NIH deputy director Raynard Kington said that an internal ethics investigation had "identified vulnerabilities in our system that give us pause".

The ban is a blow to the large scientific staff on the biomedical research agency's main campus in Bethesda, Maryland. "I think it's pretty demoralizing," said one staff member, who declined to be identified. "We're being held to a very different standard from our colleagues elsewhere."

In July, the Office of Government Ethics
(OGE) issued a sharp review of the NIH's ethics rules and its plans to modify them. The OGE is now being asked to approve the proposed moratorium. Once it has done so, a start date for the ban will be set, says Kington. That could take several months.

Kington acknowledges that it will be difficult to recruit top scientists to work at the NIH if they can't supplement their government salaries. "We will do as much as we can to make sure we have the best and the brightest," he says, although he admits that "this may very well have a negative effect".

The NIH has been under intense congressional and public scrutiny since a story in the Los Angeles Times last December revealed consulting arrangements and lecture awards that, the paper said, posed conflicts of interest (see Nature 426, 741; 2003).
The OGE blamed the problem on what it termed a "permissive climate" for deals between scientists and industry. This was implemented in 1995 by the NIH director at the time, Harold Varmus, in a bid to attract scientific talent to the agency's research laboratories from the universities.

Varmus, who now supports a ban on consulting for senior staff, says he hopes that the wider ban will not become permanent. "A complete long-term ban would be a disaster for the intramural programme," he says. "The NIH became a very attractive venue when we made it more like the outside world."

For more news and analysis go to news@nature.com www.nature.com/news 